\title{
Syrian Refugees and Community Interpreting: An Attempt at a Sociology of Translation in the Example of Sultanbeyli
}

\author{
Özgür Bülent ERDOĞAN ${ }^{I}$
}

Prof. Dr. Emine BOGENÇ DEMIREL ${ }^{2}$

\begin{abstract}
The mass arrival of refugees in Turkey from Syria since 2011 has created a growing demand for Turkish and Arabic speaking community interpreters in order to fulfill their health, educational and psychosocial needs and to facilitate their integration into Turkish society.

The district of Sultanbeyli in the periphery of Istanbul has been formed through successive waves of migration and is now home to the most important Syrian population on the Asian part of Istanbul. National and international NGOs, municipal authorities and public institutions collaborate so that Syrian refugees can benefit from psycho-social assistance and health services. Furthermore, they realize projects aiming their integration into the host society. Community interpreters play a major role in helping Syrian refugees benefit from these services and overcome linguistic and cultural barriers. Based on Bourdieu's key concepts in the sociology of translation (habitus, field, capital, illusio, doxa, self-reflexivity), our study focuses on community interpreting practices in Sultanbeyli in order to understand personal histories and linguistic dispositions of community interpreters, their
\end{abstract}

\footnotetext{
1 PhD Candidate, Ylldiz Technical University, Istanbul. Department of Translation \& Interpreting (French) blnt.rdgn@gmail.com, https://orcid.org/0000-0003-4949-4841

2 Prof. Dr., Ylldiz Technical University, Istanbul, emine.bodem@gmail.com, https://orcid. org/0000-0001-6995-2198

Research Article - Submit Date: 13.08.2020, Acceptance Date: 30.10.2020

DOI: 10.17932/IAU.IJMCL.2015.014/ijmcl_v06i2001
} 
Syrian Refugees and Community Interpreting: An Attempt at a Sociology of Translation in the Example of Sultanbeyli

roles and interactions with service providers who work at various NGOs. Ethnographic and qualitative methods were used to reveal the relationship between migration and translation.

This study is an attempt to test the above-mentioned concepts of Bourdieu forged during his experiences in Algeria and developed in France in the dynamism and fluidity of Sultanbeyli.

Keywords: Syrian refugees, Pierre Bourdieu, community interpreters, sociology of translation, NGOs (Non-Governmental Organizations)

\section{ÖZ}

2011'den itibaren Suriye'den Türkiye'ye olan kitlesel mülteci akınıla birlikte mültecilerin sağlık, eğitim ve psikososyal gereksinimlerinin karşılanması ve Türk toplumuna entegrasyonlarının kolaylaştırılması açısından Türkçe ve Arapça bilen toplum çevirmenlerine acil bir ihtiyaç oluştu.

İstanbul'un çeperlerinde bulunan Sultanbeyli, göç dalgalarıyla oluşmuş ve halen Anadolu yakasında en yoğun Suriyeli nüfusun yaşadığı ilçedir. Ulusal ve uluslararası STK'lar, belediye ve diğer kurumlar Suriyeli mültecilerin psikososyal ve sağlı hizmetlerinden yararlanmaları için birlikte çalışmakta, mültecilerin ev sahibi topluma uyumlarını sağlamak için projeler gerçekleştirmektedir. Suriyeli mültecilerin bu hizmetlerden yararlanmaları, dilsel ve kültürel engellerin aşılması açısından toplum çevirmenleri önemli bir rol oynamaktadır.

Çalışmamız Bourdieu'nün çeviri sosyolojisinde anahtar kavramlar olarak kabul edilen (habitus, alan, sermaye, illusio, doksa, özdüşünümsellik) kavramlarını temel alarak Sultanbeyli'deki toplum çevirmenliği uygulamalarına odaklanmaktadır. Toplum çevirmenlerinin kişisel tarihlerini, dilsel yatkınlıklarını, rollerini ve çeşitli STK'larda çalışan hizmet sağlayıcılarla olan etkileşimlerini ortaya çıkarmayı amaçlamaktadır. Göç ve çeviri arasındaki ilişkiselliğin ortaya çıkarabilmesi için etnografik ve nitel yaklaşımlar kullanılmıştır. $\mathrm{Bu}$ çalışma, Bourdieu'nün Cezayir deneyimleriyle oluşturduğu ve Fransa'da 
geliştirdiği bahsi geçen kavramların Sultanbeyli devingenliği ve akışkanlığında denenmesi girişimidir.

Anahtar Kelimeler: Suriyeli mülteciler, Pierre Bourdieu, toplum çevirmenleri, çeviri sosyolojisi, STK'lar (sivil toplum kuruluşları)

\section{INTRODUCTION}

Migration issues today occupy the centre stage in national and international public, linking everything in the political sense. We are currently witnessing another revolution in our age: Refugee revolution, the one which brings about fundamental changes in society just like other revolutions did in the

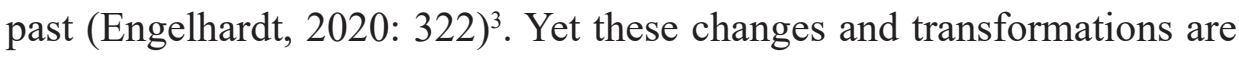
also manifest in their linguistic dimension as mass migration results in the creation of different concepts and definitions about migration. The term "refugee" in Turkish is expressed synonymously with two words: slğınmacı and mülteci, whereas göçmen and muhacir refers to "migrant." To give a definition of Syrian refugees in Turkey, Turkey has officially adopted the term "refugees under temporary protection" in 2014.

After 8 years of mass migration from Syria, Turkey is now the country that hosts the largest number of refugees worldwide ${ }^{4}$. The protests triggered by the Arab Spring in 2011 were heavily suppressed and led to the civil war in Syria. As a result, 7 million Syrians were displaced within the country and 5 million Syrians took refuge in the neighboring countries (Canefe, 2017: 33). Immediately after the outbreak of the civil war, mass migration movements from Syria into Turkey took place. This increase was felt especially in border provinces. During the first year of migration from Syria, Turkey followed an open-door policy and refugees were hosted in camps established near the border. Authorities focused mostly on emergency relief and disaster management. In the second phase of the influx, authorities started to follow

3 All English translations are mine unless indicated.

4 As reported by the UNHCR Global Report 2019, Turkey hosts 3.6 million refugees. 
Syrian Refugees and Community Interpreting: An Attempt at a Sociology of Translation in the Example of Sultanbeyli

a rather controlled entrance policy. As a result, refugees started to settle in large cities of the country. This situation occasionally creates tensions between the local population and Syrian refugees. This article discusses the relevance of Pierre Bourdieu's core concepts in the sociology of translation to elucidate the newly emerging community interpreting ${ }^{5}$ profession in Turkey as a result of the influx of Syrian refugees, specifically interpreters who are employed by local NGOs in Sultanbeyli, a conservative settlement on the outskirts of Istanbul.

In Translation studies, which is already seen as an interdisciplinary subject, has taken a sociological turn since the early 2000 s and it is evolving into an even more interdisciplinary direction as a result of current migration movements around the world. As a result of this paradigm shift in translation studies, sociological approaches have been taken up by numerous scholars from France. Pierre Bourdieu's social theory was particularly influent on these scholars who contributed to a new approach in translation studies under the name "sociology of translation". This approach takes into account multiple actors, multiple decisions taken in the making of translation, institutional constraints and the impact of global networks in translation. Methodologically, the sociology of translation views translation not merely as a textual production, but also as a product created by external and internal stakeholders. This involves a translatorial research combining internal and external sociological aspects of translation. While external sociology describes all the actors taking part in the translation process, internal sociology makes an analysis of this process. Meanwhile, it takes into account the dialectical relationship between the two (Bogenç Demirel, 2014: 40). This mass arrival of Syrian refugees in Turkey has led to a lot of mobilization in the health sector: Particularly, AFAD (Disaster and Emergency Management

$5 \quad$ Community interpreting is the type of interpreting that takes place between people who in the same community, society, or country but who do not share the same language (Hale, 2015: $65)$. 
Authority) made considerable efforts in this regard, but mostly concentrated on refugees living in the camps. Therefore, these gaps have since been filled by national NGOs and INGOs: In 2016, there were 42 national and 14 international NGOs supporting Syrian refugees in Turkey. ${ }^{6}$

According to the Association of Turkish Doctors' Alliance, health needs of the refugees are mainly centered on health issues such as malnutrition, problems in protective services and psychosocial needs: Posttraumatic stress disorders for women and children, depression and anxiety disorders. ${ }^{7}$ In addition to these problems, research conducted in Turkey recently on refugees reveals that the language barrier remains one of the most important issues, especially for women. ${ }^{8}$ Because of this situation, the demand of Arabic-Turkish speaking interpreters has been high in recent years to bridge the gap between service providers and refugees. It has been estimated that hundreds of them are employed by local NGOs all around Turkey. However, statistics on their exact numbers are unavailable.

Most interpreter positions seem to be filled in $a d h o c$, and appear to be closer to non-professional interpreting. This kind of interpreting is also known as 'natural interpreting' in which one does not need to receive formal interpreter education. Being bilingual is sufficient (Toury, 1995: 241).

That being said, efforts have been made in these organizations toward professionalization via in-house training: Community interpreting training workshops organized by other NGOs, as in the example of VHS-DVV International, affiliated to the German Adult Education Association, and its local counterpart, Beraberce in Sultanbeyli. The most recent example is the three-day workshop organized by Médecins Sans Frontières (MSF) in

\footnotetext{
6 www//medium.com/@melihcilga/suriyeli-m\%C3\%BClteciler-ve-stk-lar-12909ae7b121 (Syrian Refugees and NGO Network Map 2015), SITAP Mülteci Destek Programı STK listesi 2016. (SiTAP Refugee Support Program NGO list) [retrieved 31.01.2018]

$7 \quad$ Türk Tabipleri Birliği Suriyeli Siğınmacılar ve Sağllk Hizmetleri Raporu 2014. (Turkish Doctors'Alliance Report on Syrian Refugees and Health Services), 64.

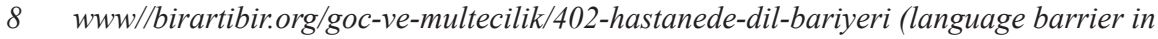
hospital). [retrieved 12.06.2019]
} 
Syrian Refugees and Community Interpreting: An Attempt at a Sociology of Translation in the Example of Sultanbeyli

collaboration with the Ardiç Solidarity Association in Istanbul.

In addition to community interpreting training, Turkish language classes are given to Arabic native speaker interpreters by the Association for Refugees (MD) in Sultanbeyli is an important step towards professionalization of community interpreters, and it is a proof that institutions pay attention to the quality of interpreting services. ${ }^{9}$

Hence, when it comes to interpreter training, the situation in Sultanbeyli seems to fit into a psycholinguistic developmental scheme. According to Whyatt, this scheme comprises of natural predisposition to language, untrained ability, trained skill, competence, and expertise. (Antonini, 2012: 49)

As seen in numerous examples of community interpreters in Sultanbeyli, encountered during our fieldwork, be it Syrian Turkmen or Syrian Arabic interpreters, both are predisposed to Turkish and Arabic languages. Turkmen interpreters have learned these languages in their childhood and although they did not receive any formal interpreting training in Syria, at least they tried to improve their Turkish, especially their writing skills. As reported by one of the Syrian Turkmen interpreters, it was possible for him to follow Turkish language classes in Damascus before coming to Sultanbeyli (Interview with a 34year-old Syrian interpreter, 14.12.2017). Regarding the interpreters whose first language is Arabic, they learned Turkish in Turkey during different circumstances such as interaction with their colleagues at work.

In migrant narratives, learning the language of the host country is seen as a test to overcome and an important step in their migration process (Deprez, 2002: 48). Learning Turkish or improving their Turkish skills stands out as a common theme highlighted in the interviews with Syrian interpreters; obviously, it is a threshold in their post-migration period in Turkey.

$9 \quad$ Arabic native speaker interpreters at the MD are to attend Turkish classes at the institution after working hours and expected to attain B2 level proficiency in Turkish language (Interview with the Project Assistant. August 2018). 


\section{CONCEPTUAL FRAMEWORK}

Bourdieu's concepts of habitus, field, capital, reflexivity and self-reflexivity are considered to be the core concepts in the sociology of translation. In addition to these, illusio and doxa were also included in our analysis of data. There were overflows from translation studies into sociolinguistics and semiotics in our analysis. Yet, a sociolinguistic analysis of our data exceeds the scope of this study.

According to Bourdieu, habitus is:

"Systems of durable, transposable dispositions, structured structures predisposed to function as structures, that is, as principles which generate and organize practices and representations that can be objectively adapted to their outcomes without presupposing a conscious aiming at ends or an express mastery of the operations necessary in order to attain them" (Bourdieu, 1990: 53).

Bourdieu developed his social theory based on his ethnographic observations in Algeria and France. In his theory of practice, Bourdieu aimed to end the duality between agency and structure. Therefore, one should question the utility of Bourdieu's concepts when applied to Sultanbeyli, a conservative suburban settlement that was formed through different layers of migration from eastern and north eastern Turkey and most recently from Syria. Do Bourdieu's concepts work in Sultanbeyli? This needs to be tested.

Getting to know these community interpreters was our first concern. In this regard, habitus was a useful concept to get to know the past, present and future of them. As Bourdieu maintains:

"The 'practical sense' precognizes; it reads in the present state the possible future states with which the field is pregnant. For in habitus the past, the present and the future intersect and interpenetrate one another"

(Bourdieu \& Wacquant, 1992: 22). 
Another essential point is to know how professional were these community interpreters, how well integrated they are to the host society, if they assume the role of cultural mediators or the link between the two communities.

\section{VOICES FROM THE FIELD: SULTANBEYLI}

The greatest hope is hidden in tomorrows which are being structured actively by the support of those who have joined our ranks as refugees (Engelhardt, 2020:330).

It is important to hear the voices in the field without which it is impossible to get a glimpse of the migration phenomenon. Therefore, we have chosen the district of Sultanbeyli, given the fact that it hosts a high number of refugees in Istanbul, attracted to the area for different reasons: affordable living, similarity of life style, social networks.

The study essentially draws on data collected during a 12-month ethnographic study which involved fieldwork including in-depth interviews with interpreters, NGO employees, refugees, some of whom are employed as full-time interpreters in these NGOs. In-depth interviews, participant observations, digital and visual materials constitute the research corpus. Fieldwork is complemented by an ethnographic analysis.

Amongst 30 persons interviewed, 14 were interpreters. The majority of them were Syrian refugees under temporary protection status. Only 3 interpreters held Turkish nationality. All data were evaluated according to Figure 1. 
FIGURE 1. Factual identity of community interpreters in Sultanbeyli

\begin{tabular}{|c|c|c|c|c|c|c|c|c|c|c|c|c|c|c|}
\hline Sütun1. & м.м. $=$ & T.C. & Y.S. & D.M & W.D. & S.N. & H.C & A.H. & M.E. & - M.H. & R.H. & B.B & A.C & M.K \\
\hline Age & 25 & 20 & 0 & 20 & 32 & 23 & 24 & 33 & 23 & 28 & 30 & 20 & 27 & 27 \\
\hline Gender & M & $M$ & M & $F$ & $M$ & $\mathrm{~F}$ & M & M & M & M & $F$ & $M$ & M & M \\
\hline Native & Turkish & Turkish & Turkish & Kurdish & Arabic & Turkish & Arabic & Arabic & Arabic & Arabic & Arabic & Arabic & Turkish & Arabic \\
\hline Nationality & Syria & Turkish & Syria & Syria & Syria & Turkish & Syria & Syria & Syria & Syria & Syria & Syria & Syria & Turkish \\
\hline City & Şam & Aleppo & Şam & Aleppo & Aleppo & Şam & Aleppo & Urfa & Aleppo & Raqqa & Aleppo & Şam & Lazkiye & Urfa \\
\hline Languages & TR-AR & TR-AR & TR-AR & TR-KR-AR & 2 TR-AR-RU & UTR-AR & TR-AR & TR-AR & TR-AR & TR-AR-EN & NTR-AR-EN & N TR-AR & TR-AR & TR-AR \\
\hline Work bef. & Designer: & Student & Interpret & etıWorker & Student & Student & Student & Teacher & Student & t Teacher & Teacher & Student & Student & t Student \\
\hline In Turkey & 6 yrs. & 2 yrs. & 5 yrs. & 4 yrs. & 3 yrs. & 5 yrs. & 4 yrs. & & 4 yrs. & 3 yrs. & 5 yrs. & 3 yrs. & 5 yrs. & \\
\hline Sultanbeyl & ¡ 3 yrs. & $4 \mathrm{~m}$. & 3.5 yrs. & $1 \mathrm{y}$. & 3 years & $1 \mathrm{y}$. & $4 y$. & $1 \mathrm{y}$. & $3 y r s$. & $6 \mathrm{~m}$. & $3 \mathrm{~m}$. & $1 \mathrm{y}$. & $1 \mathrm{y}$. & $1 y$. \\
\hline
\end{tabular}

FIGURE 2. Location of Sultanbeyli in Istanbul province

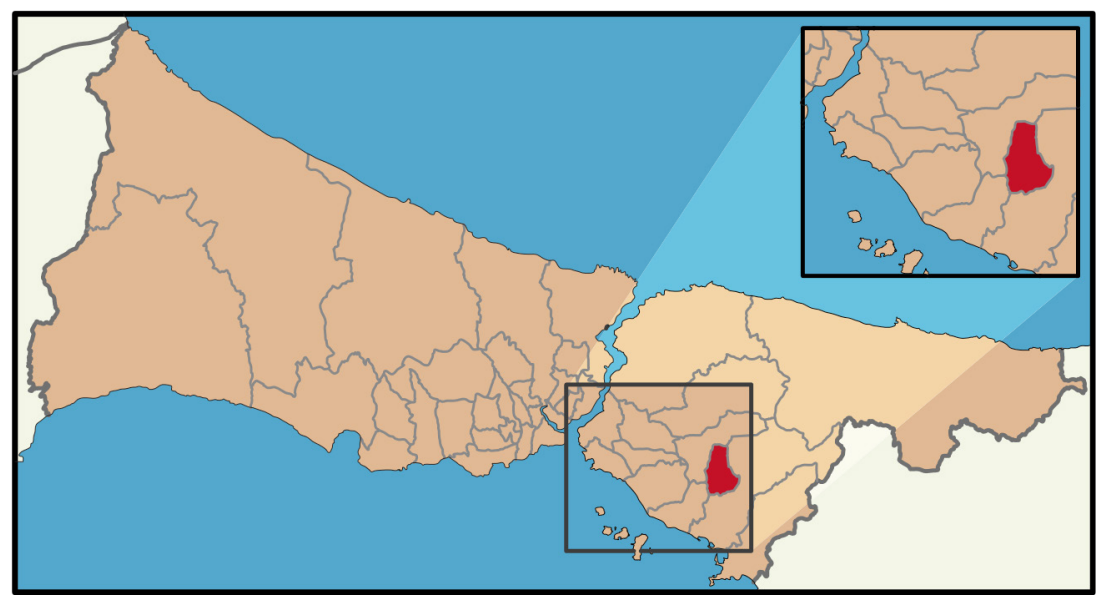

In the following pages, we will discover the migration zone of Sultanbeyli and its peculiar migration history within the history of Istanbul.

\section{SULTANBEYLI AS A MIGRATION ZONE}

The fieldwork mainly concentrated on the district of Sultanbeyli, a suburban settlement on the Asian side of Istanbul, approximately $35 \mathrm{~km}$ from the city center. According to $\mathrm{SUKOM}^{10}$ statistics, 32,000 Syrian refugees live in Sultanbeyli.

Our impressions in Sultanbeyli lead us to consider it as a fluid structure: Its

10 SUKOM is a software developed by the MD. It collects and registers data on the refugee population in Sultanbeyli. 
Syrian Refugees and Community Interpreting: An Attempt at a Sociology of Translation in the Example of Sultanbeyli

architecture and urban landscape changing almost every 5 years.

The history of Sultanbeyli is interesting in that it is made up of several layers of migration, involving different successive cultural influences. The area which now hosts 328,000 inhabitants, once belonged to one of Sultan Abdulhamid II's Ministers in the 19th century, then was bought by a Belgian Levantine called Philipson. The land was chosen as a settlement zone by Bulgarian immigrants in the 1950s, then rural migrants from North Eastern and Turkey, and Kurdish migrants from Eastern and South Eastern Turkey (Işı1k \& Pınarcıoğlu, 2009). The most recent wave of immigration since 2011 mostly came from Aleppo region in Syria.

Although one may find some similarities when compared to suburban settlements in the western world, such as the suburbs of Chicago or Turin, (Wacquant, 2008: 270) it can be said that Sultanbeyli is a unique settlement where an Islamic conservative lifestyle coexists with modern lifestyles. During our fieldwork, we have witnessed youngsters skating on the main boulevard of the city. French balcony style modern apartment buildings, as well as a replica of a Parisian café were visible on the main boulevard. 12 years after Işık \& Pınarcığlu's observations, we have witnessed an astonishing urban landscape during our field visits to Sultanbeyli:

The first time I arrived here I felt like I was in an Anatolian town. On my second visit, I've had mixed feelings of confusion and surprise. The number of malls has increased. I saw youngsters skating on the main boulevard. I immediately asked myself: Where do they belong to? To a conservative Islamic settlement? Are they from Istanbul? Maybe refugees? Also, I realized that Syrian refugees opened new stores. I saw groups of Syrian women dressed in black who were talking to each other (field notes, 07.08.2018).

There are three malls in the city with signs of international corporations 
visible from outside. It should be noted that ethnic and religious differentiation exclusive to Turkish society is also existent in Sultanbeyli. For example, there is an important Alevite community with two prayer places-Cem Houses. Tuğal asserts that Sultanbeyli went through a spatial organization from an Islamic outlook to a modern one with the accession to power of AKP since 2014. The transformation of urban landscape coincides with neoliberal orientation of the latter (Tuğal, 2015). In 2006, a modern boulevard was built in the city, where more and more women were being seen (Işık \& Pınarcioğlu, 2009: 98).

\section{SULTANBEYLI AS A TRANSLATION ZONE}

"Translation zone" concept has been used by translation scholars in different contexts. Sherry Simon sees translation as a medium by which it allows the introduction of languages into the public sphere and emphasis is more on interaction than multiplicity (Simon, 2011). Similarly, Cronin emphasizes the role translation plays in urban planning and education. It is important to see multilingual and multiethnic urban space as a translation space (Cronin, 2006). Inghillieri (2017) in her study on the relationship between migration and translation gives the example of Koreatown in Los Angeles. It is well-known that multilingual signs are visible on the urban landscape of big cities of the western world.

In Sultanbeyli, signs indicating the Anatolian roots of its inhabitants are everywhere in the form of hometown associations. As for the Syrian refugees, a street named by local residents as 'Little Aleppo' is full of stores with Arabic signs. Numerous stores owned by them are found near Turkish Red Crescent Community Center and the MD. 
Syrian Refugees and Community Interpreting: An Attempt at a Sociology of Translation in the Example of Sultanbeyli

FIGURE 3. Multilingual signs in Sultanbeyli
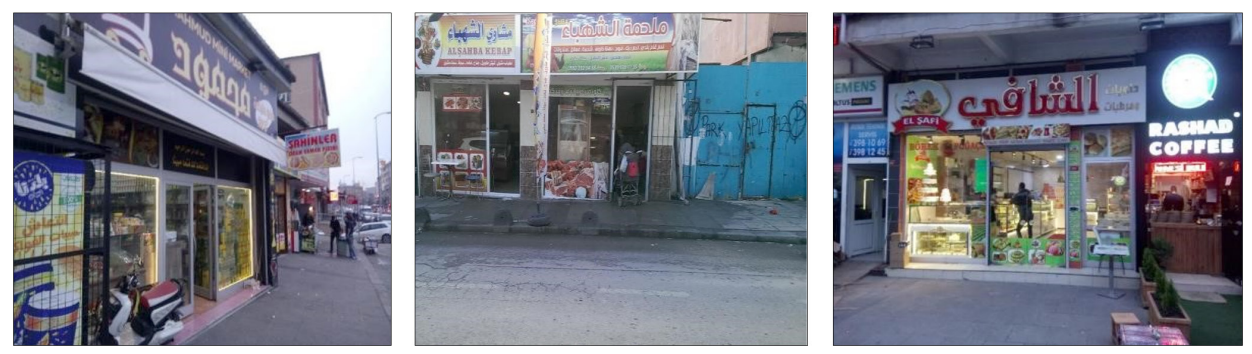

The story of Rashad Coffee like other stores in Sultanbeyli is interesting in that it shows a perfect example of how a cultural commodity like coffee travels between transnational networks involving different languages and cultures. In this case, between Syria, Brazil and Sultanbeyli. The owner of Rashad Cafe is from Damascus and has been living in Istanbul for 7 years. He speaks good Turkish and has obtained Turkish nationality recently. The café owner said that the coffee comes from a Syrian family who immigrated to Brazil from Syria a long time ago. He claims that his coffee brand will exceed other well-known coffee chains and become number one in Istanbul (field notes, 31.08.2018).

\section{THE FUNCTIONING OF COMMUNITY INTERPRETING SERVICES IN SULTANBEYLI}

In Sultanbeyli, three NGOs work with community interpreters: The Association for Refugees (MD), Turkish Red Crescent Community Center, International Blue Crescent Relief and Development Foundation (IBC).

The first one (MD) is a structure set up with the assistance of the municipality and financed by international donors. As for the Turkish Red Crescent, it is a "not-for-profit, volunteer-based social service institution, and is a corporate body governed by special legal provisions ${ }^{11}$. Community centers were founded in 2015 and there are 16 of them all around the country.

11 www.kizilay.org.tr/Kurumsal/history [retrieved 07.11.2019] 
In the MD, interpreters are exposed to random interactions within the building and some work outside. They frequently go on field visits or to hospitals. They are supposed to be present in the building from 9:00 a.m. to 6:00 p.m. and work in different departments that are divided according to specializations: legal and psychological counseling, social services, and physiotherapy. Most interpreters work in Arabic-Turkish language pairs. Kurdish, Russian, French are also spoken.

The situation in these NGOs more closely resembles the beginnings of community interpreting in some western countries, which initially set up interpreting services for migrants, then improved the system through trial and error.

\section{INTERPRETER'S HABITUS IN SULTANBEYLI}

In Bourdieu's social theory, a social space is an arena of conflict and competition where actors compete against each other to strengthen their positions in a given field. In this conflicting arena, language is one of the instances where symbolic power is manifested. Bourdieu uses concepts such as linguistic habitus and linguistic market to draw attention to the relationship between language and power relations in the social space. He describes everyday linguistic exchanges as situated encounters between actors endowed with socially structured resources and competencies (Bourdieu, 1991: 2). Therefore, every linguistic interaction carries evidence of social structure. Since interpreting occurs mostly in the form of triadic interaction, each speaker's utterance bears a trace of the social structure that it both expresses and helps to reproduce.

Since interpreters are mostly bilingual professionals, their habitus determines their roles. This also means deciding which strategy they would use during interpreting sessions. Empirical research on community interpreting launched a series of discussions about interpreter roles. Institutional expectations about community interpreters tend to see them as passive and invisible individuals 
Syrian Refugees and Community Interpreting: An Attempt at a Sociology of Translation in the Example of Sultanbeyli

subservient to institutional norms who only translate utterances from one language to another. This is usually referred to as "conduit interpreter" model. However, in practice, community interpreters take up rather different roles. They don't always conform with these norms and move on a variable ground. Indeed, empirical studies conducted in the U.S.A. (Angelelli, 2003), Canada (Barsky, 1996) and Sweden (Wadensjö, 1998), questioned the invisibility of interpreters, and revealed their intercultural mediator roles.

Data collected through interviews indicate that those who are Turkish native speakers are well aware of not only the Turkish laws, but also regional customs which may be close to those of Syrians, whereas Syrian Arabic interpreters claim that they are knowledgeable about it, and if they aren't, they strive to inform themselves by listening to Turkish social workers, or sometimes calling a friend. One interpreter said he had a friend who was a member of the Police force and called him during and after the interpreting session. It is obvious in this example that interpreter develops a translation strategy by making use of his social capital:
I know Turkey's laws and rules. I have been learning about them. I have police friends. Those I don't know; I ask them after the interview is over. Social worker knows about this situation. For example, I know that polygamy is forbidden in Turkey. I know this. I tell this to Syrian family (Interview with a 23-year-old Syrian interpreter, 29.08.2018).

Example above indicates that habitus is expanding towards different fields. Interpreter is able to step into other fields thanks to his social capital. Interpreter's social capital gained in the course of his postmigration period in Turkey has an impact on his interpreting practices. Next section will exemplify how political fields affect interpreter's habitus during his/her pre-migration period. 


\section{IMPACT OF THE POLITICAL FIELD ON THE FORMATION OF INTERPRETER'S HABITUS}

If we consider the geopolitical context in Syria before the interpreter's premigration period as a reflection of the political field, namely the external structures weighing on social actors, one can easily assert that it has an impact on the interpreter's habitus. It is a well-known fact that global and regional geopolitical developments in the world can completely change people's lives. Surely, the Syrian civil war led to the displacement of almost all of the interviewees. While starting a new life in a safer country, like Turkey, they started working as community interpreters as a strategy of survival pushed by economic necessities.

At the same time, community interpreting can be considered as a profession that allows most interviewees to be beneficial to the society in which they live. Individuals with an engineering or medical degree in Syria, may warm to the idea of working as an interpreter rather than taking a more low-profile job in Turkey. Many didn't have the idea of working as an interpreter before coming to Turkey. It seems that they stepped into this profession by chance, by accompanying other refugee families in hospitals or community centers and serving as volunteers. Some interviewees even said that they continue to work as volunteer interpreters in addition to their full-time interpreter positions.

On the other hand, the life story of Y.S. (34), one of the interviewees of Turkmen origin, is an exception to the situation of interpreters who stated that they entered into the interpreting field as volunteers. Y.S. is one of those rare refugees who started to work as an interpreter while he was a student in Damascus. He pursued his profession after he immigrated to Turkey. While Turkey-Syria relations were good, he began to accompany Turkish businessmen who regularly visited fairs in Damascus and translated for them. By doing so, he has achieved very good financial gains, because he was paid in USD. After the war broke out, he emigrated to Turkey, has started 
a new life with the help of a local businessman in Sultanbeyli (Interview with the interpreter, 14.12.2017). His social capital has been transformed into economic capital and he has gained considerable symbolic capital as an interpreter in NGOs. As can be seen from this example, there are individuals who continue to do the same work that they had started in their country professionally in Turkey. In addition, it is a concrete example showing the transformation of social networks into economic gains.

According to another interpreter, learning Russian was more important than learning Turkish while he was in Syria. He learned Turkish after emigrating to Turkey because of necessity. (Interview with the interpreter, 23.02.2018). In summary, geopolitical changes and imperatives affect which language individuals learn.

\section{LINGUISTIC HABITUS OF INTERPRETERS}

Bourdieu asserts that linguistic habitus is a by-product of social conditions and is related to a certain linguistic market (Bourdieu, 1993: 78). Moreover, it is a subset of the dispositions which comprise the habitus (Bourdieu, 1991: 17). In other words, it is only one of the dimensions of the habitus understood as a system of schemes for generating and perceiving practices (Bourdieu, 1993: 87). It should therefore be understood in relation to other schemes of practices, not separate from them. In this regard, when we look at linguistic habitus of Syrian interpreters, it is possible to identify a stratification based on their education, language skills and ethnic origin: 


\section{Syrian Turkmen Interpreter+++ (linguistic capital)} VS

\section{Syrian Arabic Interpreter- - - (linguistic capital)}

\section{Educated (university) +++ (cultural capital)}

Less educated (high school) - - - (cultural capital)

Syrians of Turkmen origin seem to be better positioned in the interpreting and translation field on the basis of their cultural capital, which also includes the linguistic capital. Those who hold Turkish nationality are positioned higher in the social space. This is confirmed by NGO employees who openly state that they prefer working with them as interpreters. On the other hand, less educated interpreters, i.e., with high school diplomas as well as Arabic mother tongue Syrian interpreters seem to hold weaker positions in the field. We believe that Bourdieu's social theory can be better understood when the whole set of his concepts are taken into consideration. In other words, habitus, field, capital, illusio, doxa, self-reflexivity all have a conceptual relationship between them and it makes more sense to use them holistically. With this in mind, we conducted a content analysis with MAXQDA 2018 software as well as word frequency of recorded interviews using Word Cloud. Consequently, some elements indicating asymmetrical power relations 
Syrian Refugees and Community Interpreting: An Attempt at a Sociology of Translation in the Example of Sultanbeyli

between other NGO employees and interpreters have appeared.

Examples below concern analysis of word frequencies used in interviews with NGO employees. In this case, with a Human Resources employee as can be seen below:

\section{Example 1:}

'Interpreters need to...' 'They are given.' 'We give interpreters...', 'they are privileged here'.

(23.02.2018)

In this example, $\mathrm{NGO}$ employee attempts to use an institutional language. Hence, this bears witness to the fragmentation of habitus and field and the emergence of doxa. Bourdieu defines doxa as a kind of unquestioned truth (Bourdieu, 1972: 164).

\section{Example 2:}

(Psychologist): Frequent use of 'I' (Interpreter) understands, to keep quiet, interpreter(s), I am trying to...

The psychologist prefers that the interpreter should keep quiet; the interpreter understands that she should keep quiet. She prefers that the interpreter should remain 'subordinate.' The emphasis on the use of $I$ and them shows an opposition between the psychologist and the interpreter. This shows the existence of asymmetrical power relations between the psychologist and the interpreter as well as class distinctions.

In addition to differences in status, we believe that immigrant identity enters into question here. In the literature on community interpreting, it has been shown that one of the roles of the interpreter is to level out uneven power relationships in the triangular communication taking place between the service provider, patient and the interpreter (Lesch, 1993, cited in Garces \& Blasi, 2010: 3). However, as seen in this example, uneven power relations persist in the communication between Syrian interpreter and Turkish psychologist. 


\section{Example 3:}

(Interpreter: Syrian Turkmen): Frequently used words: Health, medical, Turkey, Arabic, social worker, we do., we saw, we took. etc.

Focus on ' $w e$ ': This indicates the importance of teamwork between social workers, doctors and interpreters.

\section{Example 4:}

(Interpreter: Syrian Arabic): Turkish, helper, education, medicine, doctors, Arabic, Russian. Use of the first singular (I am..)

Emphasis on his education (cultural and linguistic capital): Learning Turkish is an important threshold in his life in Turkey.

\section{INTERPRETER'S ILLUSIO IN SULTANBEYLI}

Another concept which should be understood in relation to Bourdieu's key concepts is illusio. Bourdieu uses the game metaphor in order to explain the struggles going on in the social space. In this game, players are endowed with a belief that it's worth entering the game. This "worthiness" is what motivates actors to enter into the game. In other words, illusio is the commitment of players of the game in any field to invest in its stakes.

Interpreters in Sultanbeyli entered the game in the field of translation and interpreting in NGO settings with different illusio: For some, it's a step towards a higher-level position. For another one, it is about learning languages and being multilingual in an ever-changing, fluid world:

I studied English Interpreting and Translation in Syria.

My husband is Turkish. We have met here in Turkey.

After coming to Turkey, I worked in International NGOs, in the field of finance. I earned a lot of money thanks to my knowledge of languages. My child was born in Turkey... 
Syrian Refugees and Community Interpreting: An Attempt at a Sociology of Translation in the Example of Sultanbeyli

words, about life. That's why I will learn more Turkish for my daughter. I want her to learn four languages. Because the future is about languages (Interview with a 30-year-old Syrian interpreter, 08.05.2018).

In addition to the aforementioned examples, particular mention should be made of the spiritual illusio of being an interpreter, as quoted by other interpreters. For example, in this interpreter's narrative, interpreting to members of his community yields a certain spiritual power to the interpreter which takes the form of a reward (ecir) and good deed (sevap):

Interpreter finds a solution; the doctor also finds a solution...You help the patient while you translate. You improve your language skills, too. This gives me ecir and sevap. Besides, you understand that your education is not wasted... Interpreter is a mediator. He calls and assists people who are suffering. I am contacting Syrian families and helping the manager to find out which family is really in need of assistance (Interview with a 30-year-old Syrian interpreter. 13.11.2017).

This situation reminds that of a Shaman. Similarly, a Shaman starts his spiritual session with his assistant, who interprets somehow what the spirits say (Eliade, 2004: 336). In this regard, one can think of an interpreter as a spiritual assistant of the patient. The interpreter is not only a transmitter of words, but acts as a spiritual assistant. In the words of a medical interpreter interviewed, the patient is seen as an amanat. In other words, the patient is entrusted to him. He advocates the patient's rights in face of doctor's quick treatment as he feels responsible for the patient.

\section{THE ROLE OF COMMUNITY INTERPRETERS IN EASING THE TENSIONS}

As our research findings indicated in previous sections, asymmetrical power 
relationships existed between NGO employees and interpreters who were positioned at the very bottom of the hierarchy. When asymmetrical power relationships exist in a given place, tensions of various kinds become inevitable. These tensions have been observed on both macro and micro levels in Sultanbeyli.

Bourdieu pointed out that struggles and conflict can exist in a field between newcomers and those who defend monopoly of the field and dominants trying to eliminate any kind of competition:

"A field is simultaneously a space of conflict and competition, the analogy here being with a battlefield, in which participants vie to establish monopoly over the species of capital effective in it" (Bourdieu \& Wacquant, 1992: 17).

As mentioned earlier, there is a stratification between interpreters working in the NGO based on their linguistic capital, a part of their cultural capital. This leads to tensions between them. For example, Syrian Turkmen interpreters, Turkish forming the basis of their linguistic capital tend to think that their Turkish is better than the Arabic origin Syrian interpreters, although tensions between Turkmen interpreters exist, too. In the meantime, NGO employees working with interpreters show a preference to work with them as there is less risk of misunderstanding and they possess a better knowledge of terminology.

As for the NGOs in general, a struggle for funds and visibility can be observed in NGOs assisting Syrian refugees: First, between those NGOs in competition for foreign funds, in order to get more funds, NGOs resort to public relations strategies to gain more visibility and to increase their symbolic capital.

On a smaller scale, we observe a similar situation between different NGOs in Sultanbeyli. We have come across striking examples from social media accounts of these NGOs. For example, the MD invited a famous Brazilian 
Syrian Refugees and Community Interpreting: An Attempt at a Sociology of Translation in the Example of Sultanbeyli

actress, Dani Suzuki, to Sultanbeyli. She said in a quote to a local newspaper that

'Sultanbeyli's refugee policy will be a model for Brazil.' ${ }^{12}$

Whereas other NGOs are less visible, as in the example of Association of Bridging Peoples, in Izmir, which also uses community interpreters but only on a voluntary basis, it is clearly stated in its website that this NGO absolutely rejects any kind of foreign donors. ${ }^{13}$

Frequent reports of tension between Syrian refugees and the local population can be found on Turkish media. Numerous cases related to language tensions are also mentioned regarding the use of Arabic advertising billboards on stores. It seems that even in Sultanbeyli, where its religious conservative fabric might at first seem to be more hospitable and open towards Syrian refugees, several signs of unease towards their presence in the city reveals the "limits of hospitality" (Danış \& Nazl1, 2018: 6). Many examples proving this situation emerge in the narratives of Syrian community interpreters, as well.

For example, a medical interpreter of Syrian Arabic origin, M.H. related various discriminatory remarks coming from Turkish doctors with whom he worked: Some doctors keep asking me: "When will you leave here? I reply to them: Don't worry, we will leave. Just do your job (Interview with the interpreter (27) 31.08.2018).

This kind of discriminatory discourse is also heard from local shopkeepers. Syrian refugees who reside in Sultanbeyli seem to get bored with the question: Why did you come here? ${ }^{14}$

It is worth mentioning that there are conflict and competition for the distribution of limited economic resources in the city. So, it can be said that actors in

12 www.haberler.com/brezilyali-unlu-aktris-daniele-suzuki-sultanbeyli-9652165-haberi/ [retrieved 15.06.2017]

13 www.halklarinkoprusu.org/en/who-are-wel [retrieved 18.10.2018]

14 https://www.gazeteduvar.com.tr/gundem/2018/08/16/ev-arayan-suriyeliler-soruyor-nereyegidelim/[retrieved 16.07.2019] 
the migration field have entered into a struggle in the economic field based on the amount of economic capital they have. We see that new immigrants of Sultanbeyli have implemented their survival strategies thanks to their common class habitus. New immigrants are in competition with immigrants who came to Sultanbeyli decades ago.

In this context, the role of community interpreters as cultural mediators should be underlined. Their work seems to be primordial in easing tensions, eliminating prejudices and increasing mutual understanding between the host population and refugees. Although Syrian community interpreters make efforts to integrate into Turkish society not only by improving their Turkish skills but also by learning about laws, norms and customs of the host society, they are at times faced with prejudices and discriminatory remarks. This kind of profiling on the part of the established population might have an impact on the interpreter's own translation practices, however, it was impossible to measure the extent to which their interpreting job was affected by this.

One thing is certain, community interpreters are mediators in the sense that they transmit Sultanbeyli's distinctive immigration history to newcomers. As "structured actors", their habitus is transformed and they are themselves translated into the social fabric of their new city.

As for the Association for Refugees in Sultanbeyli (MD), it is a positive example where translation functions as an 'intermediate field.' This is a translational space where different languages and cultures intermingle. Translation exists in different strata in the organization: At first sight, this is highly visible in the entrance of the building. Arabic, Turkish, and German posters welcome the visitor as examples of signifiers in the building. The MD organizes activities and twinning projects aiming for mutual contacts between local residents and Syrian refugees. (Refugee assemblies, breakfast activities, tours of Istanbul, etc.).

Despite the negative examples cited above, we witnessed on various occasions that communication was possible between Turkish social workers and Syrian 
Syrian Refugees and Community Interpreting: An Attempt at a Sociology of Translation in the Example of Sultanbeyli

refugees in the building without the mediation of an interpreter. We have also witnessed some moments of effective communication between Sultanbeyli residents and Syrian refugees in public spaces such as restaurants and public transports. Therefore, there is room to believe that this was because they shared similar social and cultural references with similar habitus.

\section{CONCLUSION AND SUGGESTIONS}

Community interpreting in NGO settings is considered to be a newly emerging profession in Turkey, as it is understood from the explosion of job advertisements on specialized websites such as gelbasla.com looking for Turkish-Arabic interpreters. Their role is primordial in eliminating language barriers of refugees, especially given the actual climate of tension between the established population and Syrian refugees. Yet their visibility is still minimal.

Efforts are currently being made by other NGOs in providing training in community interpreting on the spot. Nevertheless, given the high number of Syrian refugees in Turkey, and the language barriers they face, it seems that there is not sufficient training for community interpreters, and this is a major challenge for the future.

This study focused on the district of Sultanbeyli, in the periphery of Istanbul hosting the largest number of Syrian refugees on the Asian side of the metropolis. At first glance, any visitor to Sultanbeyli could feel himself/ herself in an Anatolian city. The multilingual atmosphere of the city starts to be felt while on the bus from the center of Istanbul. Apart from different dialects of Turkish, it is likely that Arabic and Kurdish is heard. Seen from this perspective, Sultanbeyli is a migration zone. Since migration brings different cultures and languages into contact, it can also be considered as a translation zone.

In our study, sociology of translation provided a road map which included Bourdieu's core concepts (habitus, field, capital, illusio, doxa, self-reflexivity) 
as well as a glance into conditions and the actors who structured relational networks. We encountered frequent use of doxa in every phase of the research process. These included NGO employees' doxa about migration. Self-reflexivity allowed us to question our preconceived ideas about the research object, our position as a researcher in the power relations as well as the choice of research methodology. In addition to these concepts, another concept, "fluid modernity" as formulated by Zygmunt Bauman, could be useful in explaining the ever-changing nature of Sultanbeyli as a migration zone.

On a macro-level, NGOs compete against each other on the resources available to them. They are in need of funding, i.e. economic capital to be able to thrive in the NGO sector. They rely on translators in writing projects without which they wouldn't be able to function fully. Every institution enters the game with a different illusio.

On a micro-level, the building which hosts the Association for Refugees (MD) can be seen as a part of this larger translation space where different actors struggle for a place in the translation field. Each actor's position depends on the amount of linguistic capital he/she has.

In this sense, Bourdieu's approach proves to be useful. However, on a much larger scale, his concepts seem to be insufficient in explaining our current state of the world, particularly the dynamism of migration and fluidity of a metropolis like Istanbul.

This study is an attempt to provide a clear picture of community interpreting practices in peripheral Istanbul between 2017-2018 through concrete examples coming from the field. Of course, without denying the historicity of habitus, it is necessary to question the slippery and fluid aspect of this concept. Therefore, it is prudent to carry out other localized empirical research on community interpreting services in different cities in Turkey. By doing so, one may obtain a more complete picture of the current state of language needs of the refugee population and hope for a better organization 
Syrian Refugees and Community Interpreting: An Attempt at a Sociology of Translation in the Example of Sultanbeyli

of community interpreting services in Turkey.

In order to smooth out the blurriness of information about Syrian refugees,

first of all, it is necessary to raise awareness about their status and living conditions by increasing "migration literacy" amongst the local population. This will certainly lead to fluidity between locals and newcomers. Along with the proliferation of migration in Turkey, the mass has already entered into fluidity with "migration literate" citizens. As in the example of MD in Sultanbeyli, this takes the form of performances such as breakfast activities which aim to mingle local citizens with newcomers. Migration literacy would equip local population with knowledge, prepare society so that it can cope with the migration phenomenon and eventually reduce tensions. However, further research is needed to update and complement our findings in Sultanbeyli to discover the extent to which locals hold awareness of activities carried out by local NGOs to reduce tensions.

Social cohesion can be accomplished by organizing more and more artistic performances and workshops. Moreover, translation can be instrumental in breaking prejudices between cultures. Sustainable translation projects involving all actors, each acting in a reflexive and relational manner is essential to assuring mutual exchanges between people and reducing social inequalities (Bogenç Demirel, 2012: 172). NGOs can act as cultural mediators, as in the example of NGOs assisting Turkish migrants in France, this could be done by promoting and researching about the culture of the country of origin, encouraging artistic and literary production of migrant youth (Bogenç Demirel \& Bilir Ataseven, 2008: 23). Other interdisciplinary projects could be steps towards achieving migration literacy. Thus, different actors' habitus can be used in a useful manner and this would prepare the ground for better integration. 


\section{REFERENCES}

Angelelli, C. (2003). "The Interpersonal Role of the Interpreter in CrossCultural Communication”. In: Brunette, Louise; Bastin, Georges; Hemlin, Isabelle; Clarke, Heather (eds). 2003. Critical link, Amsterdam: Benjamins. Antonini, R. Cirillo L. (2017). Non-professional Interpreting and Translation: State of the art and future of an emerging field of research. John Benjamins. Barsky, R. (1996). "The Interpreter as Intercultural Agent in Convention Refugee Hearings". The translator: Studies in Intercultural Communication 2.1 Bogenç Demirel, E. \& Bilir Ataseven, F. (2008). "Intégration des immigrés turcs à travers les "médiateurs culturels." Synergies Turquie. No.1, 15-24. Bogenç Demirel, E. (2012). "Essai d'un cadre réflexif bourdieusien pour le bon sens en traduction en Turquie." Synergies Turquie. No.5, 165-173. Bogenç Demirel, E. (2014). "Çevirinin Bourdieu Sosyolojisiyle Yapılan Yönü, Çeviri Sosyolojisi”. Cogito: Pierre Bourdieu, Vol. 76.

Bourdieu, P. (1972). Outline of a Theory of Practice. Cambridge University Press.

Bourdieu, P. (1990). The Logic of Practice. Polity Press.

Bourdieu, P. (1993). Sociology in Question. Sage Publications.

Bourdieu, P. \& Wacquant L. (1992). An Invitation to Reflexive Sociology. University of Chicago Press.

Bourdieu, P. (1991). Language and Symbolic Power. Cambridge University Press.

Canefe, N. (2017). The Syrian Exodus in Context. Bilgi Üniversitesi Yayınları. Cronin, M. (2006). Translation and Identity. Routledge.

Danış, D. \& Nazlı, D. (2018). “A Faithful Alliance Between the Civil Society and the State: Actors and Mechanisms of Accommodating Syrian Refugees in Istanbul," International Migration. Vol. 57, No. 2.

Deprez, C. (2002). "La langue comme "épreuve" dans les récits de migration" VALS-ASLA (Association suisse de linguistique appliquée) Vol. 76, pp. 39-52. Eliade, M. (2004). Shamanism. Princeton University Press. 
Syrian Refugees and Community Interpreting: An Attempt at a Sociology of Translation in the Example of Sultanbeyli

Engelhardt, M. (2020). Siğıımacı Devrimi (translated by İlknur Aka). YKY Yayınları.

Hale, S. (2015). “Community interpreting” Pöchhacker, F. Ed. Routledge Encyclopedia of Interpreting Studies.

Inghillieri, M. (2017). Translation and Migration. Routledge.

Işık, O. \& Pınarcıoğlu, M. (2009). Nöbetleşe Yoksulluk: Gecekondulaşma ve Kent Yoksullarl: Sultanbeyli Örneği. İletişim Yayınları.

Simon, S. (2011). Cities in Translation: Intersections of Language and Memory. Routledge.

Toury, G. (1995). Descriptive Translation Studies and Beyond. John Benjamins Publishing Company.

Tuğal, C. (2015). “The Islamic Making of a Capitalist Habitus” in Comparing European Workers: Part A. 85-112

Valero-Garces, C. \& Blasi, L.G. (2010). Bourdieu and Public Service Interpreting and Translation: Towards a social theory in PSIT. MonTI 2trans. Wacquant, L. (2008). Urban Outcasts: A Comparative Sociology of Advanced Marginality. Polity Press.

Wadensjö, C. (1998). Interpreting as Interaction. Longman.

Internet sources

Syrian Refugees and NGO Network Map, 2015.www//medium.com/@ melihcilga/suriyelim\%C3\%BClteciler-ve-stk-lar-12909ae7b121

Language barrier in hospital. www//birartibir.org/goc-ve-multecilik/402hastanede-dil-bariyeri.

Turkish Red Crescent. www.kizilay.org.tr/Kurumsal/history.

Dani Suzuki in Sultanbeyli. www.haberler.com/brezilyali-unlu-aktris-danielesuzuki-sultanbeyli9652165-haberi/

Association for Bridging Peoples. www.halklarinkoprusu.org/en/who-are-we/ https://www.gazeteduvar.com.tr/gundem/2018/08/16/ev-arayan-suriyelilersoruyor-nereye-gidelim/ 